\title{
Dental implants in patients treated with antiresorptive medication - a systematic literature review
}

\author{
Christian Walter ${ }^{1 *}$, Bilal Al-Nawas ${ }^{1}$, Tim Wolff $^{2}$, Eik Schiegnitz $^{1}$ and Knut A. Grötz ${ }^{2}$
}

\begin{abstract}
Objective: Bisphosphonate-associated osteonecrosis of the jaws (BP-ONJ) is triggered by inflammatory processes. Typical trigger factors are periodontal disease, denture pressure sores, and surgical interventions such as tooth extractions. Unfortunately there is only little data on how to proceed with implant therapy in patients with bisphosphonate treatment. This topic is not addressed in the German guidelines on medication-associated osteonecrosis. Therefore a systematic literature review was performed.

Methods: The PICO design was used: (Patients) For which subclientel of patients with antiresorptive therapy (intervention) do dental implants have a benefit (control) compared to forgoing dental implants (outcome) in regards to oral rehabilitation and quality of life without having a substantial risk of BP-ONJ development? A PubMed search was performed including all studies dealing with this topic. Case reports and studies with less than 5 cases were excluded.

Results: There is only very little data available, mostly retrospective case series. 50 articles were analyzed in detail. BP-ONJ can be triggered by dental implants and by dentures in patients with benign and malignant primary diseases. In most studies, analyzing osteoporosis patients only, no cases of BP-ONJ were observed in patients with implant therapy in the time span observed. There are no studies about implant therapy in patients with malignant diseases. Many case series analyzing the trigger factors for BP-ONJ describe dentures as one of the main causes. Perioperative antimicrobial prophylaxis has a benefit in the prevention of BP-ONJ development.

Conclusion: Successful implant therapy is possible in patients receiving antiresorptive therapy. The possibility of osteonecrosis development needs to be explained to the patient. An individual risk assessment is essential, taking the primary disease with the medication and further wound-healing-compromising diseases and medications into account. If possible, bone augmentations should be avoided, and a perioperative antimicrobiological prophylaxis is strongly recommended in these patients.
\end{abstract}

Keywords: Bisphosphonate associated osteonecrosis of the jaws, Bisphosphonate, Dental implant, Denture, Augmentation, Sinus lift, Antibiotics, Quality of life

\footnotetext{
* Correspondence: walter@mkg.klinik.uni-mainz.de

${ }^{1}$ Department of Oral and Maxillofacial Surgery - Plastic Surgery of the Johannes Gutenberg-University Mainz, Augustusplatz 2, 55131 Mainz, Germany

Full list of author information is available at the end of the article
} 


\section{Introduction}

Bisphosphonate-associated osteonecrosis of the jaws (BP-ONJ) is a well-known side effect in patients receiving bisphosphonates (BP) due to e.g. osteoporosis, multiple myeloma or malignant diseases with metastases to the bone; prevalences range between $0.1 \%$ for patients with primary osteoporosis to $1 \%$ in patients with secondary osteoporosis and up to about $20 \%$ for special high risk subpopulations of patients with a malignant disease and further predisposing factors [1, 2]. In addition to general risk factors such as the primary disease implicating the antiresorptive therapy, the antiresorptive therapy itself, concomitant diseases and medications and other influencing systemic factors usually a further factor triggering the development of BP-ONJ can be identified such as periodontal disease, extractions, denture pressure sores, or implant insertion [3, 4]. Usually BP-ONJ occurs in patients of higher ages (69 years \pm 10 years [3]) due to the primary disease causing the BP therapy so that it is not unusual that these patients seek the dentist for oral rehabilitation where implant therapy and bone augmentation for optimal implant positioning might be considered to substitute lost teeth.

There are guidelines describing $\mathrm{BP}$ treatment as a contraindication for implant therapy in patients with an oncologic primary disease $[5,6]$ that say implant insertion should be avoided $[7,8]$. On the other hand, there are studies describing the safety of dental implant surgery in patients with oral $\mathrm{BP}$ and osteoporosis with no occurring BP-ONJ cases [5]. However, there are cases of successful implant insertion in patients with malignant primary diseases and cases of BP-ONJ in patients with osteoporosis $[9,10]$. Reviews mention that there are only very few retrospective studies with moderate strength of evidence addressing this topic [11] so that no final recommendation can be given [12]. Oral and intravenous $\mathrm{BP}$ are not seen as absolute contraindications for dental implant therapy and that dental implants can osseointegrate successfully. It is recommended to do a risk assessment and to inform the patient about the potential risk of BP-ONJ development [11-13].

A similar scenario is well known in patients with radiation of the jaws. Initially, radiation therapy was seen as a contraindication for implant insertion [14] because of osteoradionecrosis. In Germany meanwhile, implants are covered by the health insurance by law in some of these patients (\$28 SGB V Sozialgesetzbuch). Due to xerostomia sufficient fixation of a denture is rather complicated, and implants can improve the situation and might reduce the incidence of osteoradionecrosis by avoiding pressure denture sores that could result in exposed bone and eventually osteoradionecrosis.

This development could be transferred to patients with antiresorptive treatment (bisphosphonates, denosumab) since implants might reduce the incidence of BP-ONJ due to the lack of denture pressure sores in these patients. As well, denture pressure sores have been described by many authors as the triggering factor for BP-ONJ [15].

The German guidelines on bisphosphonate- and medication-associated osteonecrosis of the jaws state that there might be a limitation in the indication of implant insertion in these patients, but the implant-based oral rehabilitation was not a part of these guidelines [1] To address this deficit in the literature, the rationale of this literature review was to find out which patients with antiresorptive therapy (BP, denosumab) benefit from dental implants without being exposed to an unreasonable high risk of osteonecrosis development.

\section{Review \\ Methods}

A systematic review was performed in accordance with the preferred reporting items for systematic reviews and meta-analyses protocols (PRISMA-P),

\section{Focused question}

The review was performed using the PICO design.

Patients: For which subclientel of patients with antiresorptive therapy

Intervention: do dental implants have a benefit Control: compared to forgoing dental implants Outcome: in regards to oral rehabilitation and quality of life without having a substantial risk of BP-ONJ development.

\section{Search strategy}

In June 2015, a PubMed search was performed by TW looking for all available articles; no limitation on the publication date was imposed. The search was modified by $\mathrm{CW}, \mathrm{BA}, \mathrm{ES}$ and KAG so that 24 more articles were identified.

To address the topics, the search terms bisphosphonate and denosumab were used in combination with the following search terms: osteonecrosis, jaw, dental implants, periimplantitis, denture, augmentation, sinus lift, antibiotics, xerostomia, CTX, medication time, masticatory efficiency, tmj disorder, prevention, oral health related quality of life [NOT oral cavity cancer], prognosis dental implant, persisting alveolar socket, sharp bone edges [NOT children NOT osteogenesis imperfecta, ossification [NOT children NOT osteogenesis imperfecta], bone remodeling, and post extraction [NOT children NOT osteogenesis imperfecta]. 17 articles were added due to the manual search (Table 1 and Fig. 1). 
Table 1 PubMed literature search with the total number of hits for each topic and the number of included articles for each topic. For each topic the search terms (ST) are given

\begin{tabular}{|c|c|c|}
\hline Topic & Identified $(n)$ & Included $(n)$ \\
\hline \multicolumn{3}{|l|}{ Outcome osteonecrosis risk. ST (bisphosphonate OR denosumab) AND osteonecrosis jaw AND } \\
\hline Dental implant OR periimplantitis & 105 & 18 \\
\hline Denture & 49 & 12 \\
\hline Jaw augmentation OR sinus lift & 7 & 0 \\
\hline Antibiotics AND dental implant & 16 & 0 \\
\hline Xerostomia & 4 & 0 \\
\hline CTX & 35 & 0 \\
\hline Medication time & 16 & 0 \\
\hline \multicolumn{3}{|l|}{ Outcome mastification. ST } \\
\hline Masticatory efficiency AND dental implant & 61 & 0 \\
\hline TMJ disorder AND dental implant AND prevention & 10 & 0 \\
\hline \multicolumn{3}{|l|}{ Outcome quality of life. ST (bisphosphonate OR denosumab) AND } \\
\hline Quality of life AND dental implant & 5 & 1 \\
\hline Oral health related quality of life AND dental implant & 1 & 0 \\
\hline \multicolumn{3}{|l|}{ Outcome prognosis remaining dentition. ST (bisphosphonate OR denosumab) AND } \\
\hline Prognosis remaining dentition AND dental implant & 0 & 0 \\
\hline \multicolumn{3}{|l|}{ Outcome prognosis future implants. ST (bisphosphonate OR denosumab) AND } \\
\hline Dental implant AND prognosis & 16 & 0 \\
\hline Persisting alveolar socket & 2 & 2 \\
\hline Sharp bone edges AND jaw NOT children NOT osteogenesis imperfecta & 2 & 0 \\
\hline Ossification AND jaw NOT children NOT osteogenesis imperfecta & 66 & 0 \\
\hline Bone remodeling AND post extraction AND jaw NOT children NOT osteogenesis imperfecta & 7 & \\
\hline Radiologic changes AND jaw NOT children NOT ostegenesis imperfect AND dental implant & 1 & 0 \\
\hline Hand search & & 17 \\
\hline Total & 403 & 50 \\
\hline
\end{tabular}

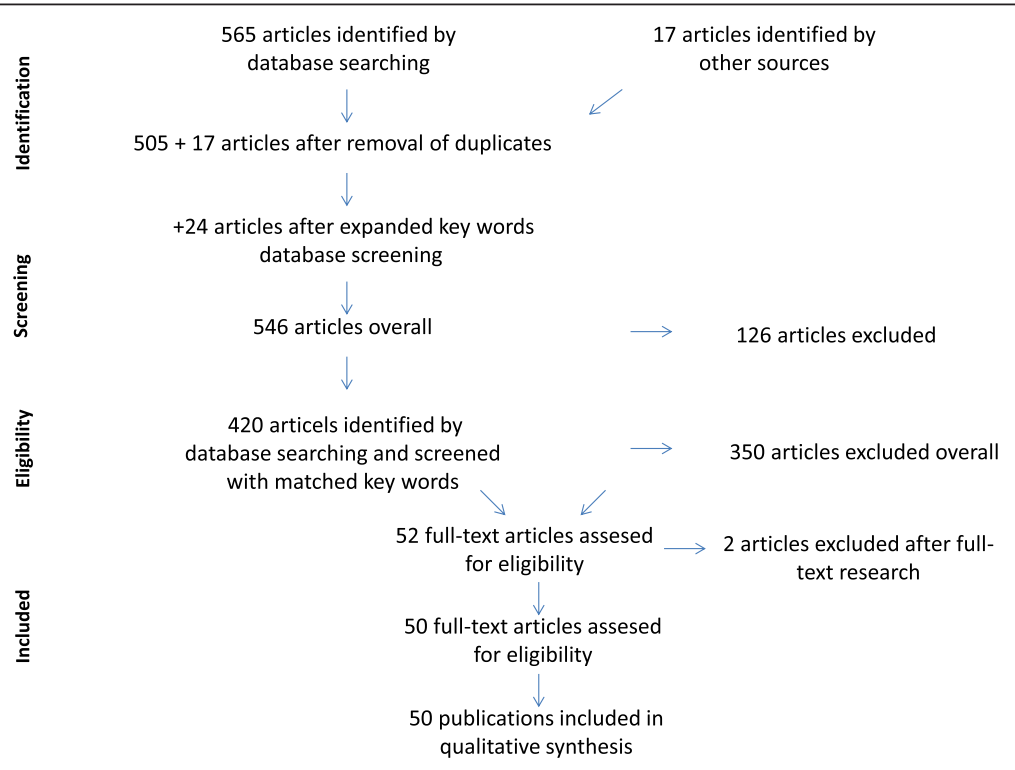

Fig. 1 Flow diagram of literature search and selection 


\section{Study inclusion and exclusion criteria}

Inclusion criteria were:

Prospective (randomized controlled, non-randomized controlled, cohort) and retrospective studies (controlled, case control, single cohort) and case series dealing with dental implants in patients with antiresorptive therapy. Studies that had less than five patients or cases were excluded as well as studies whose cases lacked data or were not clearly defined. The studies had to be published in either English or German.

Studies that did not meet the inclusion criteria were excluded.

In the first step, the titles and abstracts were screened for eligibility. In the second step, all full-articles were evaluated.

\section{Quality assessment of selected studies}

Due to the available data, an explicit quality assessment was not performed.

\section{Data extraction and method of analysis}

A table was generated and used to collect the relevant information.

\section{Results}

Out of 606 articles 556 articles were excluded because they were either duplicates, case reports, narrative reviews, case series with less than 5 cases or were not associated with the topic at all (Table 1 and Fig. 1). Some of the articles analyzed more than one outcome and are referred to several times. Since the available literature is very inhomogeneous with a low level of evidence a statistical analysis was not performed and the following results are descriptive only.

\section{Dental implants/periimplantitis}

The literature dealing with this topic can roughly be separated into three groups:

a. BP-ONJ case series exclusively triggered by implants in patients with malignant and benign diseases [9, 10, 16-19],

b. BP-ONJ case series analyzing case series of BP-ONJ of which varying amounts are caused by implants in part among patients with malignant and benign diseases [20-23] and

c. implant studies performed exclusively in patients with benign diseases, mostly osteoporosis [24-31]. In very few of these studies, the primary disease was not given, but the prescribed bisphosphonates strongly suggest osteoporosis as the primary disease (see Table 2).

In the BP-ONJ case series (a) and (b), the distribution of BP-ONJ patients between malignant and benign diseases is more or less even, e.g. Holzinger describes 13 patients: 5 osteoporosis, 3 breast cancer, 3 multiple myeloma, 1 lung cancer and 1 Langerhans cell histiocytosis patient [9]. Lopez-Cedrun exclusively found patients with benign diseases: 8 osteoporosis and 1 polymyalgia rheumatic. Jacobsen found 14 patients: 5 osteoporosis, 5 breast cancer, 2 multiple myeloma, 1 prostate and 1 lung cancer patient.

However, implant studies (c) were exclusively performed in patients with benign diseases. Nearly all of these studies do not report a single BP-ONJ triggered by the implant insertion.

A systematic review analyzing the sparse literature on clinical denosumab trials mentioning osteonecroses did not describe dental implants as a trigger [32].

There is no literature describing periimplantitis in these patients.

\section{Denture}

The literature dealing with this topic can be separated into two groups:

a. BP-ONJ case series for which varying amounts are caused by dentures in patients with malignant and benign diseases [2, 33-42] and

b. studies performed on BP patients with dentures analyzing the frequency of BP-ONJ [15, 43].

Here as well, no imbalance regarding the dignity of the primary disease could be found. Jabbour describes 2 osteoporosis, 1 kidney and 1 breast cancer patient [35]. Kumar found 4 osteoporosis patients, 1 breast cancer patient and 1 patient with multiple myeloma.

Nibbe [15] analyzed 128 patients with IV BP or denosumab separated into 3 groups. In the first group 5 out of 60 patients with no denture had an osteonecrosis (8\%), in the 2nd group 5 out of 34 patients with a fixed partial denture had an osteonecrosis 15\%, and in the 3rd group 11 out of 34 patients with a removable denture had an osteonecrosis (32\%). Kyrgidis determined that dentures increase the risk of BP-ONJ development [38].

\section{Augmentation/sinus lift/antibiotics/xerostomia/CTX}

There was no literature available meeting the inclusion criteria. There is evidence in the literature that sinus lifts can be successful [28] and might contribute to BP-ONJ development [18].

\section{Outcome masticatory efficiency/TMJ disorder}

There was no literature available meeting the inclusion criteria. 
Table 2 Included literature

\begin{tabular}{|c|c|c|c|c|c|c|c|c|c|c|}
\hline \multicolumn{11}{|l|}{ Implant } \\
\hline \multirow[t]{2}{*}{$\begin{array}{l}\text { Author Year } \\
\text { Reference }\end{array}$} & \multirow[t]{2}{*}{ Study type } & \multirow[t]{2}{*}{ Patients } & \multirow[t]{2}{*}{$\begin{array}{l}\text { Primary disease } \\
\text { in BP patients ( } n \text { ) }\end{array}$} & \multirow[t]{2}{*}{$\begin{array}{l}\text { BP BP-Th } \\
\text { (years } \\
\text { min- max) }\end{array}$} & \multirow[t]{2}{*}{$\begin{array}{l}\text { BP-ONJ } \\
\text { cases due } \\
\text { to implants }\end{array}$} & \multirow[t]{2}{*}{ Implants (n) } & \multicolumn{3}{|c|}{$\begin{array}{l}\text { Implant insertion in all } \\
\text { patients (patients [n]) } \\
\text { Point of time }\end{array}$} & \multirow[t]{2}{*}{ Comment } \\
\hline & & & & & & & $\begin{array}{l}\text { before BP } \\
\text { therapy }\end{array}$ & $\begin{array}{l}\text { during BP } \\
\text { therapy }\end{array}$ & $\begin{array}{l}\text { after BP } \\
\text { therapy }\end{array}$ & \\
\hline $\begin{array}{l}\text { Al-Sabbagh } \\
2015[24]\end{array}$ & RS CS & $\begin{array}{l}203 \text { patients with } 515 \\
\text { implants; } 20 \text { out of } \\
\text { those patients with } \\
\text { osteoporosis and oral BP }\end{array}$ & Osteoporosis 20 & Oral $\mathrm{BP}>3$ & 0 & 46 & n.s. & n.s. & n.s. & $\begin{array}{l}\text { All patients with implant therapy } \\
\text { from 08/2000 until 05/2004 were } \\
\text { contacted and data was collected } \\
\text { by interview (in person/per } \\
\text { telephone). } 203 \text { patients with } 515 \\
\text { implants; in } 20 \text { patients ( } 46 \text { implants) } \\
\text { with osteoporosis and oral BP no } \\
\text { ONJ occurred no implant was lost. } \\
\text { There is no data regarding the } \\
\text { implant success in the patients } \\
\text { without osteoporosis. }\end{array}$ \\
\hline $\begin{array}{l}\text { Nisi } \\
2015 \text { [20] }\end{array}$ & RS CS & $\begin{array}{l}90 \text { patients with } \\
\text { established ONJ } \\
\text { some of them } \\
\text { with implants }\end{array}$ & Malignoma 90 & Z n.s. & 9 & n.s. & n.s. & n.s. & n.s. & $\begin{array}{l}\text { All patients with BP-ONJ from } \\
01 / 2004 \text { until 12/2015 were } \\
\text { retrospectively analyzed. 78\% } \\
\text { had an additional radiation. It } \\
\text { is not clear if the head and } \\
\text { neck region was affected and } \\
\text { if the implant patients were } \\
\text { affected. The study describes } \\
\text { the cumulative BP dose, smoking, } \\
\text { steroid intake and the maxillary } \\
\text { location as risk factors for an } \\
\text { increases BP-ONJ stage. }\end{array}$ \\
\hline $\begin{array}{l}\text { Holzinger } \\
2014 \text { [9] }\end{array}$ & RS CS & $\begin{array}{l}13 \text { patients with } \\
\text { established ONJ } \\
\text { due to dental } \\
\text { implants }\end{array}$ & $\begin{array}{l}\text { Osteoporosis } 5 \\
\text { breast cancer } 3 \\
\text { lung cancer } 1 \\
\text { Langerhans cell } \\
\text { histiocytosis } 1\end{array}$ & $\begin{array}{l}\text { Z A P I } \\
-0.5-9 \\
0-15.6\end{array}$ & 13 & 47 & 3 & 7 & 3 & $\begin{array}{l}\text { All patients with BP-ONJ from 04/ } \\
2004 \text { - 07/2012 were analyzed. } \\
\text { Among those were } 13 \text { patients } \\
\text { (47 implants) with implants as a } \\
\text { trigger. } 30 \text { implants had to be } \\
\text { removed.lt takes longer for BP- } \\
\text { ONJ development if implants are } \\
\text { placed during or after BP } \\
\text { treatment compared to } \\
\text { implants being inserted } \\
\text { before BP treatment. }\end{array}$ \\
\hline $\begin{array}{l}\text { Lopez-Cedrun } \\
2013 \text { [10] }\end{array}$ & RS CS & $\begin{array}{l}9 \text { Patients with } \\
\text { established ONJ } \\
\text { due to dental } \\
\text { implants }\end{array}$ & $\begin{array}{l}\text { Osteoporosis } \\
\text { Polymyalgia } \\
\text { rheumatica }\end{array}$ & $\begin{array}{l}\text { A I R } \\
0.5-10\end{array}$ & 9 & 57 & - & 9 & - & $\begin{array}{l}\text { Retrospective multicenter study } \\
\text { analyzing all patients with BP- } \\
\text { ONJ due to dental implants } \\
\text { from 01/2009 - 06/2012.The } \\
\text { authors state that the ONJ was } \\
\text { more common in the mandible } \\
\text { (8/9) and more often in the } \\
\text { premolar and molar region. } 28\end{array}$ \\
\hline
\end{tabular}


Table 2 Included literature (Continued)

\begin{tabular}{|c|c|c|c|c|c|c|c|c|c|c|}
\hline & & & & & & & & & & \\
\hline $\begin{array}{l}\text { Tam } \\
2013[16]\end{array}$ & RS CS & $\begin{array}{l}6 \text { patients with } \\
\text { established BP-ONJ } \\
\text { due to dental } \\
\text { implants }\end{array}$ & $\begin{array}{l}\text { Osteoporosis } 4 \\
\text { breast cancer } 1 \\
\text { multiple myeloma } 1\end{array}$ & A Z1.5-6 & 6 & & - & 6 & - & $\begin{array}{l}\text { All patients with BP-ONJ due } \\
\text { to dental implants from } 2009 \text { - } \\
2011 \text { were analyzed; } 3 \text { patients } \\
\text { with BP-ONJ in the posterior } \\
\text { maxilla } 3 \text { patients with BP-ONJ } \\
\text { in the mandible ( } 2 \text { distal, } 1 \text { anterior) }\end{array}$ \\
\hline $\begin{array}{l}\text { Kwon } \\
2014 \text { [17] }\end{array}$ & RS CS & $\begin{array}{l}19 \text { patients with } \\
\text { established BP-ONJ } \\
\text { due to dental } \\
\text { implants }\end{array}$ & $\begin{array}{l}\text { Osteoporosis } 18 \\
\text { multiple myeloma } 1\end{array}$ & $\begin{array}{l}\text { A I P R Z } \\
1-5\end{array}$ & 19 & n.s. & 3 & 16 & - & $\begin{array}{l}\text { All patients with BP-ONJ due to } \\
\text { dental implants from } 06 / 2008 \text { - } \\
12 / 2011 \text { were analyzed. } 8 \text { patients } \\
\text { with BP-ONJ in the maxilla, } 9 \\
\text { patients with BP-ONJ in the } \\
\text { mandible, } 2 \text { patients with BP-ONJ } \\
\text { in mandible and maxilla }\end{array}$ \\
\hline $\begin{array}{l}\text { Jacobsen } \\
2013[18]\end{array}$ & RS CS & $\begin{array}{l}14 \text { patients with } \\
\text { established BP-ONJ } \\
\text { due to dental implants }\end{array}$ & $\begin{array}{l}\text { Osteoporosis } 5 \\
\text { Breast cancer } 5 \\
\text { multiple myeloma } 2 \\
\text { prostate cancer } 1 \\
\text { lung cancer } 1\end{array}$ & $\begin{array}{l}\text { A I P } \\
\text { ZAverage BP } \\
\text { duration3.2 } \\
\text { osteoporosis; } \\
4.2 \text { malignant } \\
\text { disease }\end{array}$ & 14 & n.s. & n.s. & n.s. & n.s. & $\begin{array}{l}\text { The authors state that implants } \\
\text { placed posterior are of higher } \\
\text { risk than implants in the anterior } \\
\text { region. } 4 \text { patients had implants } \\
\text { in the posterior maxilla, } 5 \text { in the } \\
\text { posterior mandible and } 3 \text { in the } \\
\text { anterior mandible.In one patient } \\
\text { implants were removed and new } \\
\text { implants were inserted at the } \\
\text { same site with continuing } \\
\text { problems.In one patient a sinus } \\
\text { lift was performed }\end{array}$ \\
\hline $\begin{array}{l}\text { Famili } \\
2011[25]\end{array}$ & RS CS & $\begin{array}{l}211 \text { female patients } \\
\text { with } 592 \text { dental } \\
\text { implants, out of } \\
\text { those } 120 \text { older } \\
\text { than } 50 \text { y with } \\
347 \text { implants out } \\
\text { of those } 22 \text { with } \\
\text { BP and } 75 \text { implants }\end{array}$ & $\begin{array}{l}\text { Osteoporosis } 21 \\
\text { osteoarthritis } 1\end{array}$ & $A \mid<1->5$ & 0 & 75 & n.s. & At least 20 & n.s. & $\begin{array}{l}\text { All female patients with implant } \\
\text { therapy from 01/2008 - 06/2010 } \\
\text { were analyzed. Among those } 22 \\
\text { with oral BP therapy. One implant } \\
\text { did not heal and was successfully } \\
\text { replaced }\end{array}$ \\
\hline $\begin{array}{l}\text { Kwon } \\
2011 \text { [21] }\end{array}$ & $\begin{array}{l}\text { RS CCS but } \\
\text { not focused } \\
\text { on dental } \\
\text { implants } \rightarrow \\
\text { RS CS }\end{array}$ & $\begin{array}{l}\text { Biochemical bone } \\
\text { markers were } \\
\text { evaluated in } 23 \\
\text { osteoporosis } \\
\text { patients with } \\
\text { established BP-ONJ }\end{array}$ & Osteoporosis & $A 2.5-5$ & 2 & n.s. & n.s. & n.s. & n.s. & $\begin{array}{l}\text { It is not clear, when and how the } \\
23 \text { BP-ONJ patients were recruited. } \\
61 \text { BP control patients.2 patients } \\
\text { developed BP-ONJ due to implants } \\
\text { CTX was evaluated at the time of } \\
\text { ONJ diagnosis and not at the time } \\
\text { point of any possible BP-ONJ } \\
\text { triggering intervention. }\end{array}$ \\
\hline $\begin{array}{l}\text { Koka } \\
2010 \text { [22] }\end{array}$ & RS CS & $\begin{array}{l}370 \text { patients over } \\
50 \text { years old with } \\
818 \text { implants. } 233 \\
\text { patients could not }\end{array}$ & Osteoporosis & $\begin{array}{l}\text { A \& n.s. } \\
<3->5\end{array}$ & 0 & 121 & - & 55 & - & $\begin{array}{l}\text { All patients from 11/2006 - 05/2009 } \\
\text { that had not denied access to data } \\
\text { for research purposes. None of the } \\
\text { BP patients had a drug holiday. } 121\end{array}$ \\
\hline
\end{tabular}


Table 2 Included literature (Continued)

\begin{tabular}{|c|c|c|c|c|c|c|c|c|c|c|}
\hline & & $\begin{array}{l}\text { that the phone } \\
\text { interview was } \\
\text { conducted with } \\
\text { remaining } 137 \\
\text { patients: } 55 \mathrm{BP} \\
\text { patients and } 82 \\
\text { non-BP patients }\end{array}$ & & & & & & & & $\begin{array}{l}\text { implants were inserted, one did not } \\
\text { survive.The patients were not } \\
\text { examined only a phone interview } \\
\text { was conducted.The control group } \\
\text { consisted of } 82 \text { non-BP users with } \\
166 \text { implants ( } 163 \text { survived, } 2 \text { losses } \\
\text { in } 1 \text { patient). } 233 \text { patients could not } \\
\text { be reached by phone and were } \\
\text { excluded. }\end{array}$ \\
\hline $\begin{array}{l}\text { Lazarovici } \\
2010 \text { [19] }\end{array}$ & RS CS & $\begin{array}{l}27 \text { patients with } \\
\text { established ONJ } \\
\text { due to dental } \\
\text { implants }\end{array}$ & $\begin{array}{l}\text { Osteoporosis } 11 \\
\text { multiple myeloma } 7 \\
\text { breast cancer } 7 \\
\text { prostate cancer } 2\end{array}$ & $\begin{array}{l}\text { A P Z } \\
\text { average } \\
\text { BP duration } \\
\text { A } 5.7 \\
\text { Z } 1.4 \\
\text { P } 4.2\end{array}$ & 27 & n.s. & 2 & 25 & - & $\begin{array}{l}\text { All patients from 04/2003 - 01/2009 } \\
\text { with BP-ONJ and dental implants. } 15 \\
\text { patients had implants in the posterior } \\
\text { mandible, } 5 \text { in the anterior mandible, } \\
4 \text { in the posterior maxilla, } 3 \text { in the } \\
\text { anterior maxilla }\end{array}$ \\
\hline $\begin{array}{l}\text { Goss } \\
2010 \text { [26] }\end{array}$ & RS CS & $\begin{array}{l}\text { Questionnaire to } \\
46 \text { dentists placing } \\
\text { either }>50 \text { implants/y } \\
\text { or treat BP-ONJ in } \\
\text { South Australia }\end{array}$ & $\begin{array}{l}\text { Osteoporosis in the } 7 \\
\text { patients with implant } \\
\text { loss }\end{array}$ & $\begin{array}{l}\text { A R in the } 7 \\
\text { patients with } \\
\text { implant loss }\end{array}$ & 7 & $\geq 9$ & 4 & 3 & - & $\begin{array}{l}46 \text { dentists placed approximately } \\
28,000 \text { implants in } 16,000 \text { patients. } \\
\text { There is no number given how } \\
\text { many patients received BP. } 7 \text { implants } \\
\text { were lost in patients with BP }\end{array}$ \\
\hline $\begin{array}{l}\text { Lo } \\
2009 \text { [27] }\end{array}$ & $\begin{array}{l}\text { RS CS } \\
\text { questionnaire }\end{array}$ & $\begin{array}{l}\text { Questionnaire to } \\
13,496 \text { patients with } \\
\text { oral BP therapy, } 8,572 \\
\text { answered, } 2,159 \\
\text { reported dental } \\
\text { symptoms, } 1005 \\
\text { were examined, } \\
9 \text { BP-ONJ }\end{array}$ & n.s. & $A \mid R \geq 1$ & 1 & n.s. & n.s. & n.s. & n.s. & $\begin{array}{l}13,946 \text { questionnaires were sent, } \\
5,374 \text { did not participate, } 9 \text { ONJ } \\
\text { were identified and } 1 \text { was associated } \\
\text { with an implant loss and a tooth } \\
\text { extraction. The bisphosphonates } \\
\text { had been administered before } \\
\text { implant insertion }\end{array}$ \\
\hline $\begin{array}{l}\text { Bell } \\
2008 \text { [28] }\end{array}$ & RS CS & $\begin{array}{l}42 \text { patients with } \mathrm{BP} \\
\text { therapy and oral } \\
\text { bone grafting or } \\
\text { implant placement }\end{array}$ & n.s. & A R I & 0 & $\begin{array}{l}100 \text { or } 101 \\
\text { both } \\
\text { numbers } \\
\text { are given } \\
\text { in the paper }\end{array}$ & - & 42 & - & $\begin{array}{l}\text { All patients from ??/1990 - ??/???? } \\
\text { (paper published in 2008) with BP } \\
\text { treatment prior to implant therapy } \\
\text { were analyzed. } 5 \text { implants failed, no } \\
\text { patient with more the } 1 \text { implant loss, } \\
\text { all implants successfully replaced.30 } \\
\text { patients received an additional bone } \\
\text { augmentation (socket graft, sinus lift, } \\
\text { closed sinus lift, guided tissue } \\
\text { regeneration, or tunnel graft). }\end{array}$ \\
\hline $\begin{array}{l}\text { Grant } \\
2008 \text { [29] }\end{array}$ & RS CS & $\begin{array}{l}\text { Questionnaire to all } \\
1,319 \text { female patients } \\
\text { over } 40 \text { y and with implants, } \\
458 \text { patients responded, } \\
115 \text { out of those had oral BP, } \\
72 \text { patients came to a } \\
\text { follow-up }\end{array}$ & n.s. & $\begin{array}{l}\text { A I R } \\
\text { Mean } 3.2\end{array}$ & 0 & $\begin{array}{l}456 \text { in the } \\
115 \text { patients }\end{array}$ & $\begin{array}{l}\text { 26out of } \\
\text { the } 115\end{array}$ & $\begin{array}{l}89 \text { out of } \\
\text { the } 115\end{array}$ & - & $\begin{array}{l}\text { All 1,319 patients over } 40 \text { y of age } \\
\text { with implant therapy between } \\
01 / 1998 \text { - 12/2006 were contacted. }\end{array}$ \\
\hline $\begin{array}{l}\text { Fugazotto } \\
2007[30]\end{array}$ & RS CS & $\begin{array}{l}61 \text { patients out of two } \\
\text { private practices with } \\
\text { oral BP }\end{array}$ & n.s. & $\begin{array}{l}\text { A R } \\
\text { Mean } 3.3\end{array}$ & 0 & 169 & - & 61 & - & $\begin{array}{l}\text { All } 61 \text { patients with oral bisphosphonates } \\
\text { with implant therapy between 01/2005- } \\
12 / 2005 \text { were analyzed. } 43 \text { immediate }\end{array}$ \\
\hline
\end{tabular}


Table $\mathbf{2}$ Included literature (Continued)

\begin{tabular}{|c|c|c|c|c|c|c|c|c|}
\hline $\begin{array}{l}\text { Jeffcoat } \\
2006[31]\end{array}$ & PS & $\begin{array}{l}50 \text { patients with } \\
210 \text { implants } 25 \\
\text { patients with } \\
\text { oral BP } 102 \\
\text { implants } 25 \\
\text { patients without } \\
\text { BP } 108 \text { implants }\end{array}$ & Osteoporosis 25 & A R1 - 4 & 102 & 102 & - & $\begin{array}{l}\text { Longitudinal single-blind controlled } \\
\text { studyTwo-stage osseointegrated } \\
\text { implants in all patients,no BP-ONJ }\end{array}$ \\
\hline $\begin{array}{l}\text { Marx } \\
2005[23]\end{array}$ & RS CS & $\begin{array}{l}119 \text { patients } \\
\text { with BP-ONJ }\end{array}$ & $\begin{array}{l}\text { n.s. for the } \\
\text { patients with } \\
\text { implants }\end{array}$ & $\begin{array}{l}\text { n.s. for the } 4 \\
\text { patients with } \\
\text { implants,in } 1 \\
\text { case Z \& P }\end{array}$ & n.s. & n.s. & n.s. & $\begin{array}{l}\text { RS with } 119 \text { ONJ patients, } 4 \text { due } \\
\text { to dental implants }\end{array}$ \\
\hline \multicolumn{9}{|l|}{ Denture } \\
\hline $\begin{array}{l}\text { Author Year } \\
\text { Reference }\end{array}$ & & Study type & Patients & $\begin{array}{l}\text { Primary Disease } \\
\text { in BP-ONJ }\end{array}$ & BP/Denosumab & $\begin{array}{l}\text { BP-ONJ } \\
\text { Cases }\end{array}$ & \multicolumn{2}{|c|}{ Comment } \\
\hline $\begin{array}{l}\text { Nibbe } \\
2015 \text { [15] }\end{array}$ & & RS & $\begin{array}{l}424 \text { patients with } \\
\text { oral/IV BP or } \\
\text { denosumab. } 128 \\
\text { patients with IV BP or } \\
\text { denosumab - further } \\
\text { investigation of this } \\
\text { group68 patients } \\
\text { with dentures }\end{array}$ & n.s. in all cases & $\begin{array}{l}\text { Oral/IV BP } \\
\text { Denosumab }\end{array}$ & 16 & \multicolumn{2}{|c|}{$\begin{array}{l}424 \text { patients with oral or IV BP were analyzed, } \\
21 \text { BP-ONJ, only IV BP patients for further } \\
\text { analysis34 removable dentures } \rightarrow 11 \text { BP-ONJ34 } \\
\text { fixed partial denture } \rightarrow 5 \text { BP-ONJ60 patients } \\
\text { without denture } \rightarrow 5 \text { BP-ONJONJ only in } \\
\text { patients with IV BP or denosumab }\end{array}$} \\
\hline $\begin{array}{l}\text { Hasegawa } \\
2012[43]\end{array}$ & & RS & $\begin{array}{l}\text { Questionnaire was } \\
\text { sent to } 248 \text { medical } \\
\text { institutions regarding } \\
\text { BP-ONJ250 pa- } \\
\text { tients99 with den- } \\
\text { tures151 without } \\
\text { dentures }\end{array}$ & n.s. & Oral/IV BP & 99 & \multicolumn{2}{|c|}{$\begin{array}{l}151 \text { osteonecrosis patients without } \\
\text { denture had a longer osteonecrosis } \\
\text { free time.Most ONJ in the mandible } \\
\text { with a focus on the premolar and } \\
\text { molar region154 patients with IV BP, } \\
102 \text { with oral BP, } 7 \text { both }\end{array}$} \\
\hline $\begin{array}{l}\text { Jabbour } \\
2012[35]\end{array}$ & & RS & $\begin{array}{l}14 \text { patients with } \\
\text { BP-ONJ4 due to } \\
\text { dentures }\end{array}$ & $\begin{array}{l}\text { Osteoporosis } \\
\text { 2kidney cancer } \\
1 \text { breast cancer } 1\end{array}$ & A P & 4 & \multicolumn{2}{|c|}{ RS analyzing the reason for osteonecroses } \\
\hline $\begin{array}{l}\text { Vahtsevanos } \\
2009[39]\end{array}$ & & RS & $\begin{array}{l}\text { 1,621 patients } \\
\text { with IV BP }\end{array}$ & n.s. & $\begin{array}{l}\text { n.s. for the } \\
\text { denture } \\
\text { patients }\end{array}$ & 24 & \multicolumn{2}{|c|}{$\begin{array}{l}24 \text { out of } 80 \text { BP-ONJ patients denture as } \\
\text { triggering factor diseases and BP for the } \\
\text { patients with dentures } n . S . I P Z Z \text { were } \\
\text { used as BP in the BP-ONJ patients. }\end{array}$} \\
\hline Kos 2010 [36] & & RS & $\begin{array}{l}34 \text { patients with } \\
\text { BP-ONJ }\end{array}$ & n.s. & $\begin{array}{l}\text { n.s. for denture } \\
\text { patients }\end{array}$ & 3 & \multicolumn{2}{|c|}{$\begin{array}{l}34 \text { patients with osteonecrosis. A I P R Z } \\
\text { were used as BP it is not clear what the } \\
\text { patients with the dentures received } \\
\text { and which primary disease was present. } \\
\text { BP-therapy for all patients } 0.3-8 y\end{array}$} \\
\hline
\end{tabular}

mplants1 Pat had exposed bone at a debridement. At the next control the was granulated soft tissue.

indinal single-blind controlled studyTwo-stage osseointegrated

implants25 BP 108 implants

n.s. for the
n.s. for the
implants,in
case Z \& P

Author Yea

Primary Diseas

n.s. in all cases

oral/IV BP or

patients with IV BP or

BP-ONJ250 pa-

tients99 with den-

dentures

2kidney cancer

dentures

east cancer

n.s. for the

denture

n.s. for denture 
Table 2 Included literature (Continued)

\begin{tabular}{|c|c|c|c|c|c|c|}
\hline $\begin{array}{l}\text { Carmagnola } \\
2008[34]\end{array}$ & RS & $\begin{array}{l}39 \text { oncologic patients } \\
\text { with BP }\end{array}$ & $\begin{array}{l}\text { Multiple myeloma } 2 \\
\text { breast cancer } 3 \\
\text { prostate cancer } 1 \\
\text { kidney cancer } 1\end{array}$ & PZ & 7 & $\begin{array}{l}7 \text { out of } 20 \mathrm{BP}-\mathrm{ONJ} \text { patients had an } \\
\text { osteonecrosis due to denture pressure } \\
\text { soresBP given for } 1.1-6.8 \mathrm{y}\end{array}$ \\
\hline Walter 2008 [40] & CSS & $\begin{array}{l}43 \text { patients with } \\
\text { prostate cancer out } \\
\text { of those } 21 \text { patients } \\
\text { with denture out of } \\
\text { those } 6 \text { with ONJ }\end{array}$ & Prostate cancer & Z & 1 & 1 denture induced ONJ \\
\hline Kyrigidis 2008 [38] & CCS & $\begin{array}{l}20 \text { breast cancer } \\
\text { patients } 40 \text { matched } \\
\text { controls }\end{array}$ & Breast Cancer & Z & 8 & $\begin{array}{l}20 \text { patients with breast cancer and } \\
\text { osteonecrosis, } 8 \text { with dentures use of } \\
\text { dentures associated with BP-ONJ }\end{array}$ \\
\hline Kumar 2008 [37] & RS CS & $\begin{array}{l}13 \text { patients with BP- } \\
\text { ONJ }\end{array}$ & $\begin{array}{l}\text { Osteoporosis } 4 \\
\text { breast cancer } 1 \\
\text { multiple myeloma } 1\end{array}$ & $A Z$ & 6 & $\begin{array}{l}6 \text { out of } 13 \text { patients denture as the } \\
\text { trigger factor }\end{array}$ \\
\hline Yarom 2007 [42] & RS CS & $\begin{array}{l}11 \text { patients with BP- } \\
\text { ONJ }\end{array}$ & Osteoporosis & A & 2 & $\begin{array}{l}2 \text { out of } 11 \text { BP-ONJ triggered by } \\
\text { denture Alendorante was given } \\
\text { for } 2 \text { and } 6 \text { y } 2 \text { patients ( } 1 \text { osteoporosis, } \\
1 \text { rheumtoid arthritis) had an implant } \\
\text { related BP-ONJ in the posterior mandible, } \\
\text { BP was given for } 5 \text { and } 7 \text { years }\end{array}$ \\
\hline Walter 2007 [41] & RS CS & $\begin{array}{l}163 \text { patients with an } \\
\text { osteonecrosis, } 17 \mathrm{BP} \text { - } \\
\text { ONJ }\end{array}$ & Multiple Myeloma & $P$ & 1 & $\begin{array}{l}1 \mathrm{BP}-\mathrm{ONJ} \text { due to a denture pressure } \\
\text { sore in the mandibleP was given for } 5 \mathrm{y}\end{array}$ \\
\hline Bamias 2005 [33] & PS & $\begin{array}{l}252 \text { patients with } \\
\text { BP17 with BP-ONJ }\end{array}$ & Multiple Myeloma & n.s. & 2 & $\begin{array}{l}2 \text { BP-ONJ due to a denture pressure sore } \\
\text { I P Z for all } 252 \text { patients }\end{array}$ \\
\hline \multicolumn{7}{|l|}{ Quality of life } \\
\hline $\begin{array}{l}\text { Author Year } \\
\text { Reference }\end{array}$ & \multicolumn{3}{|l|}{ Patients } & \multicolumn{3}{|c|}{ Comment } \\
\hline DeBaz 2015 [44] & \multicolumn{3}{|c|}{$\begin{array}{l}524 \text { patients asked to fill } \\
\text { out the survey } 237 \text { completed } \\
\text { survey3 groups: } 64 \text { dental } \\
\text { implant supported prosthesis } \\
47 \text { non-implant supported } \\
\text { fixed restoration60 non-implant } \\
\text { supported removable restoration } \\
66 \text { no restoration of missing teeth }\end{array}$} & \multicolumn{3}{|c|}{$\begin{array}{l}\text { The quality of life assessment: } \\
\text { occupational scorehealth } \\
\text { scoreemotional scoresexual score } \\
\text { The patients dental implant } \\
\text { supported prosthesis had the } \\
\text { overall best score regarding quality } \\
\text { of life compard to the other } \\
\text { groupsIn total } 134 \text { patients reported } \\
\text { oral BP, } 51 \text { IV BP, } 10 \text { patients } \\
\text { denosumabln the implant group } \\
35 \text { patients received oral BP, } 12 \text { IV } \\
\text { BP, } 3 \text { denosumabno ONJ }\end{array}$} \\
\hline \multicolumn{7}{|l|}{ Persisting alveolar socket } \\
\hline Author Year Reference & Study type & \multicolumn{2}{|l|}{ Patients } & \multicolumn{3}{|c|}{ Comment } \\
\hline Hutchinson 2010 [46] & CSS & \multicolumn{2}{|l|}{$\begin{array}{l}10 \text { patients with } \\
\text { stage } 0 \text { BP-ONJ }\end{array}$} & \multicolumn{3}{|c|}{$\begin{array}{l}\text { Consistent findings of regional } \\
\text { or diffuse osteosclerosis, density }\end{array}$} \\
\hline
\end{tabular}


canal, thickened sclerotic lamina

dura, periradicular radiolucencies,

cortical disruption, and persisting

alveolar sockets.

Grötz
$2006[45]$

RS CS

Hand search

Author Year

Reference

Grötz

$2012[1]$

Grötz [52]

Grötz

Review

2013 [53]

Grötz

2010 [54]

Review

Krimmel

2014 [55]

Tsao

CCS

2013 [56]
Study type

42 patients with BP-ONJ

Patients

Consistent findings of persisting alveolar sockets.

Comment

German guidelines on bisphosphonate-

associated osteonecrosis of the jaws

(BP-ONJ) and other medication-related

necroses of the jaw

Description on many important aspects

on implant surgery in bisphosphonat

patients or patients with onosphonate

patients or patients with other resorptive patications.

The authors state the necessity for an individual risk assessment. The

evaluation of dentures vs. implants.

t is suggested to not place immediate

implants in patients with antiresorptive therapy, atraumatic surgery with

perioperative antibiotics, the necessity

of a recall and the avoidance of bone

augmentations

The authors provide an algorithm how to proceed with patients receiving BP seeking implant therapy.The authors state the necessity for an individual risk assessment and avoidance of bone augmentations

DMFT of all patients $20.5 \pm 4.2$

disease free interval for patients with DMFT < 20: $39.7 \pm 1.1$ months disease free interval for patients

with DMFT > 20: $14.4 \pm 2.8$ months The DMFT had no influence on the overall healing rate of BP-ONJ

Caries similar between groups

Periodontal disease associated with BP-ONJ (pocket depth, IgG serum titer against Porphyromonas
63 patients 22 BP-ON

controls 
Table 2 Included literature (Continued)

\begin{tabular}{|c|c|c|c|}
\hline $\begin{array}{l}\text { Martin } \\
2010[58]\end{array}$ & CSS & $\begin{array}{l}8,752 \text { patients with oral } \\
\text { BP returned dental survey } \\
\text { (62\% response rate) } \\
589 \text { patients with dental } \\
\text { implants }\end{array}$ & $\begin{array}{l}16 \text { patients with } 26 \text { implant failures } \\
8 \text { patients with failure of } 12 \text { implants } \\
\text { in the maxilla9 had failure with } 14 \\
\text { implants in the mandible }\end{array}$ \\
\hline $\begin{array}{l}\text { Shabestari } \\
2009[59]\end{array}$ & RS & $\begin{array}{l}21 \text { female osteoporotic } \\
\text { women with oral BP } \\
\text { and } 46 \text { implants }\end{array}$ & No BP-ONJ, no signs of peri-implantitis \\
\hline $\begin{array}{l}\text { Zahid } \\
2011[60]\end{array}$ & RS & $\begin{array}{l}362 \text { patients with implants } \\
26 \text { BP patients with } 51 \text { implants }\end{array}$ & $\begin{array}{l}3 \text { implants failedPatients with BP } \\
\text { had more thread exposure }\end{array}$ \\
\hline $\begin{array}{l}\text { Memon } \\
2012[61]\end{array}$ & RS & $\begin{array}{l}200 \text { patients } \\
\text { BP: } 100 \text { women with } \\
153 \text { implantscontrol: } \\
100 \text { women with } 132 \text { implants }\end{array}$ & $\begin{array}{l}\text { Success equal for both groups } 93.5 \\
\text { (BP) vs. } 95.5 \text { (control)crestal bone } \\
\text { change from implant insertion to } \\
\text { stage two surgery: no difference } \\
\text { between the groups }\end{array}$ \\
\hline $\begin{array}{l}\text { Yip } \\
2012[62]\end{array}$ & CCS & $\begin{array}{l}337 \text { patients } \\
114 \text { patients with implant failure } \\
223 \text { patients without implant failure }\end{array}$ & $\begin{array}{l}\% \text { of patients using BP } \\
\text { Implant failure group: } 9.65 \% \\
\text { no implant failure: } 4.04\end{array}$ \\
\hline $\begin{array}{l}\text { Walter } \\
2014[3]\end{array}$ & RS & $\begin{array}{l}504 \text { patients with osteonecrosis } \\
227 \text { with BP-ONJ }\end{array}$ & $\begin{array}{l}7 \text { out of } 227 \text { patients with } \\
\text { BP-ONJ implant as trigger factor }\end{array}$ \\
\hline $\begin{array}{l}\text { Lopez-Jornet } \\
2011[63]\end{array}$ & Animal study & $\begin{array}{l}120 \text { rats with pamidronate } \\
\text { treatment and molar extraction } \\
60 \text { with penicillin60 without penicillin }\end{array}$ & $\begin{array}{l}\text { Osteonecrosis rate } \\
\text { Penicillin group: } 18 \rightarrow 34.6 \% \\
\text { no penicillin group: } 5 \rightarrow 9.61 \%\end{array}$ \\
\hline $\begin{array}{l}\text { Montefusco } \\
2008[51]\end{array}$ & RS & $\begin{array}{l}178 \text { patients with multiple myeloma } \\
\text { und BP treatment } \\
75 \text { patients with dental procedures } \\
32 \text { with antibiotics } 43 \text { without antibiotics }\end{array}$ & $\begin{array}{l}\text { ONJ rate } \\
\text { with antibiotics: } 0 \\
\text { without antibiotics: } 8 \\
\text { Antibiotic prophylaxis can } \\
\text { reduce the incidence of BP-ONJ }\end{array}$ \\
\hline $\begin{array}{l}\text { Kyrgidis } \\
2012[50]\end{array}$ & PS & $\begin{array}{l}\text { Group 1: BP-ONJ breast cancer } 21 \\
\text { Group 2: breast cancer } 21 \\
\text { Group 3: oral cancer } 22\end{array}$ & $\begin{array}{l}\text { Quality of life assessment before surgery } \\
\text { Group } 1 \text { is affected in many factors such } \\
\text { as pain, swallowing, senses, social eating, } \\
\text { social contacts }\end{array}$ \\
\hline $\begin{array}{l}\text { Boquete-Catro } \\
2015 \text { [32] }\end{array}$ & Review & $\begin{array}{l}\text { Analysis of patients with denosumab } \\
\text { associated ONJ }\end{array}$ & No implant related ONJ reported \\
\hline
\end{tabular}

gingivalis, IL $1 ß$ level in gingival

Thumbigere-Math

2013 [57]

patients

25 BP-ONJ patients

48 matched controls

BP infusions BP-ONJ 38.4 and

control 18.8

BP-ONJ vs controlmissing teeth:

7.8 vs 3.1 clinical attachment level:

7.8 vs $3.1 \mathrm{cmical}$ attachment level:

56 radiogic bone loss a

eeth > 50\%: $20 \%$ vs. $6 \%$

ients with failure of 12 implants

the maxilla9 had failure with 14

Success equal for both groups 93.5

(BP) Vs. 95.5 (control)crestal bone

D.

No implant related ONJ reported

A: Alendronate; CCS: Case control study, CS: Case series; CSS:
Study; R: Risedronate; RS: Retrospective study, Z: Zoledronate 


\section{Outcome quality of life (QoL)}

There is nearly no literature available on the change of the quality of life due to implants in patients with antiresorptive therapy. One article could be identified [44] that analyzed the quality of life in partially edentulous osteoporosis patients that were restored with (1) a dental implant-supported prosthesis, (2) a non-implantsupported fixed restoration, (3) a non-implant-supported removable restauration, and (4) no restoration that showed a statistically significant difference regarding the improvement of the QoL in patients with a dental implant-supported prosthesis compared to the other sub-groups. Out of the 237 patients, 134 patients had an oral BP and 51 patients an IV BP therapy [44].

\section{Outcome remaining dentition}

No articles could be found regarding the prognosis of the remaining dentition depending on implant therapy, neither for patients with bisphosphonate nor denosumab treatment.

\section{Outcome future implants}

There are no reliable parameters indicating the success of implants in patients with anti-resorptive therapy. The risk of osteonecrosis development has already been described in the chapter referring to the osteonecrosis risk. Two articles mentioned the radiologic finding of a persisting alveolar socket as a marker indicating the osteonecrosis risk [45, 46]. In addition, other radiologic changes in patients with bisphosphonates have been described, such as regional or diffuse osteosclerosis, confluence of cortical and cancellous bone, prominence of the canal of the inferior alveolar nerve, a prominent lamina dura, radiolucences around the apex and cortical disruptions [46]. Their existence reflects the changes in the bone remodeling due to the anti-resorptive therapy and might be associated with a higher osteonecrosis risk, but there is no evidence supporting this theory.

\section{Discussion}

Even latest guidelines and statements dealing with medication associated osteonecrosis of the jaws such as the American [7, 8], Scottish [47], Swiss [6] or German [1] do not address implant therapy in these patients in detail. Due to this lack of data a systematic literature review was performed to fill this gap. Unfortunately the literature dealing with this topic is very sparse and consists mainly of case reports, case series, and a few retrospective studies. Regarding the topics augmentation, masticatory efficiency, TMJ and the impact on the remaining dentition no literature met the inclusion criteria or no literature was available at all.

Surgical procedures such as implant insertion and potential complications such as periimplantitis are associated with an inflammatory condition and can potentially trigger a BP-ONJ. The risk of developing BP$\mathrm{ONJ}$ is higher the more potent the $\mathrm{BP}$ are and the longer they were administered [1]. There is lots of literature supporting dental implant therapy in patients with antiresorptive medication in benign primary diseases, with only a few patients developing BP-ONJ (Table. 2). In contrast, the literature regarding successful implant therapy in malignoma patients is very sparse. The majority of publications on malignoma patients describes scenarios with BP-ONJ development (Table 2).

In many cases a denture would be the alternative treatment option to dental implants but many BP-ONJ cases in patients with benign and malignant diseases are caused by denture pressure sores (Table 2), so when deciding whether a patient is eligible for implant therapy, this fact should be considered as well. The consideration needs to take into account how much the patient might benefit from the implant itself, the risk of causing an osteonecrosis due to the procedure and the likelihood of preventing an osteonecrosis by avoiding dentures and denture pressure sores.

In the consideration of a potential implant insertion the need for a bone augmentation or a sinus lift needs to be considered as well. Although there are only very few cases in the literature with augmentation of bone/sinus lift $[18,28]$, these procedures are linked to a functioning vascular recipient site with working osteoclastic resorption and osteoblastic bone formation, and this is compromised in patients with antiresorptive therapy. Due to the denudation of the bone at the recipient site the vascular situation might be even more compromised, possibly resulting in more BP-ONJ cases so that any kind of augmentation should be considered with extreme care.

Dental implants can improve the Qol in patients with antiresorptive therapy (bisphosphonate/denosumab) [44] analogous to patients without antiresorptive therapy [48]. A recently performed systematic review on masticatory performance, bite force, nutritional state and patient's satisfaction showed that implant-supported dentures were associated with high patient satisfaction regarding denture comfort and bite force. But interestingly these outcomes were not always related with an increase in general QoL [49]. There is no reason, why this should be any different in patients with antiresorptive therapy in the event of implant success. On the other hand the occurrence of BP-ONJ has a huge impact on the QoL of affected patients since the patients report higher negative affection by pain, problems swallowing and social eating even compared to patients with head and neck squamous cell carcinoma [50]. Therefore prevention of BP-ONJ should be one of the primary aims.

The risk of triggering a BP-ONJ by implant therapy in patients with benign diseases seems to be rather small. 
The risk in patients with malignant diseases is hard to describe since mostly negative examples are published but not the total number of patients receiving implant therapy. The distribution clearly illustrates the necessity for an individual risk assessment as it is recommended by most guidelines and the importance of explaining the possibility of BP-ONJ development to the patient. The individual risk is influenced by the primary disease and its treatment, such as the antiresorptive medication (substance, duration of application, frequency of application), concomitant therapy, further diseases (e.g. diabetes), further treatments (e.g. head and neck radiation), further factors (e.g. smoking) and existence of former osteonecrosis/present osteonecrosis. Next to this, the patients need to be compliant with an appropriate motivation for oral hygiene and the necessary skills to transfer this. Infectious foci should be treated before implant therapy to further reduce the risk of osteonecrosis development. The surgical sites should be followed up clinically (persisting sharp bone edges without any tendency to remodel) and radiologically (e.g. persisting alveolar sockets) to identify a compromised wound healing that might be associated with a higher BP-ONJ risk.

The use of bone markers is discussed controversially in the literature, and no clear recommendation can be given at the moment $[1,8]$. In these cases, where an implant is planned, a perioperative antimicrobial prophylaxis should be administered, similar to the prophylaxis suggested in other surgical procedures performed in these patients, since this seems to be a tool to decrease BP-ONJ frequency $[1,51]$. There is no literature on patients with antiresorptive medications other than bisphosphonates, and so the recommendation is to proceed with these patients similarly to patients on bisphosphonates.

Unfortunately literature with high evidence is rare. Dental implants are possible in patients with antiresorptive therapy but an individual risk assessment should be performed and alternative treatment options should be considered keeping the scenario of BP-ONJ development in mind. Implant survival and success rate alone are not sufficient to evaluate the implant supported rehabilitations in patients with bisphosphonates. Even more important is the risk of triggering an osteonecrosis in relation to the possible gain of QoL by an implant supported therapy.

\section{Conclusions}

Successful implant therapy is feasible in patients receiving antiresorptive therapy. The risk of osteonecrosis development needs to be explained to the patient. An individual risk assessment is essential, taking the primary disease with the medication and further wound-healingcompromising diseases and medications into account. If possible, bone augmentations should be avoided, and a perioperative antimicrobiological prophylaxis is strongly recommended in these patients.

\section{Abbreviations}

BP: bisphosphonate; BP-ONJ: bisphosphonate-associated osteonecrosis of the jaws; CTX: C-terminal telopeptide of the type I collagen; PICO: patients intervention control outcome; PRISMA-P: preferred reporting items for systematic reviews and meta-analyses protocols; QoL: quality of life;

ST: search term; TMJ: temporomandibular joint.

\section{Competing interests}

The authors Christian Walter, Bilal Al-Nawas, Tim Wolff, Eik Schiegnitz, and Knut A. Grötz declare that they have no competing interests.

\section{Authors' contributions}

All authors designed the review. TW made the primary literature acquisition that was evaluated by the other others. All authors interpreted the data. CW drafted the manuscript that was revised by the other authors. All authors read and approved the final manuscript.

\section{Author details}

${ }^{1}$ Department of Oral and Maxillofacial Surgery - Plastic Surgery of the Johannes Gutenberg-University Mainz, Augustusplatz 2, 55131 Mainz, Germany. ${ }^{2}$ Department of Oral and Maxillofacial Surgery of the Dr. Horst Schmidt Clinic, Ludwig-Erhard-Str. 100, 65199 Wiesbaden, Germany.

Received: 26 September 2015 Accepted: 23 March 2016

Published online: 04 April 2016

References

1. Grötz KA, Piesold JU, Al-Nawas B. Bisphosphonat-assoziierte Kiefernekrose (BP-ONJ) und andere Medikamenten-assoziierte Kiefernekrosen. 2012. AWMF online.

2. Walter C, Al-Nawas B, Frickhofen N, Gamm H, Beck J, Reinsch L, et al. Prevalence of bisphosphonate associated osteonecrosis of the jaws in multiple myeloma patients. Head Face Med. 2010;6:11. doi:10.1186/1746160X-6-11.

3. Walter C, Sagheb K, Bitzer J, Rahimi-Nedjat R, Taylor KJ. Analysis of reasons for osteonecrosis of the jaws. Clin Oral Investig. 2014;18(9):2221-6. doi:10. 1007/s00784-014-1205-6.

4. Walter C, Laux C, Sagheb K. Radiologic bone loss in patients with bisphosphonate-associated osteonecrosis of the jaws: a case-control study. Clin Oral Investig. 2014;18(2):385-90. doi:10.1007/s00784-013-0974-7.

5. Madrid C, Sanz M. What impact do systemically administrated bisphosphonates have on oral implant therapy? A systematic review. Clin Oral Implants Res. 2009;20 Suppl 4:87-95. doi:10.1111/j.1600-0501.2009.01772.x.

6. Borm JM, Moser S, Locher M, Damerau G, Stadlinger B, Gratz KW, et al. Risk assessment in patients undergoing osseous antiresorptive therapy in dentistry. An update. Schweiz Monatsschr Zahnmed. 2013;123(11):985-1001. 955.

7. Advisory Task Force on Bisphosphonate-Related Ostenonecrosis of the Jaws AAoO, Maxillofacial S. American Association of Oral and Maxillofacial Surgeons position paper on bisphosphonate-related osteonecrosis of the jaws. J Oral Maxillofac Surg. 2007;65(3):369-76. doi:10.1016/j.joms.2006.11.003.

8. Ruggiero SL, Dodson TB, Fantasia J, Goodday R, Aghaloo T, Mehrotra B, et al. American Association of Oral and Maxillofacial Surgeons position paper on medication-related osteonecrosis of the jaw-2014 update. J Oral Maxillofac Surg. 2014;72(10):1938-56. doi:10.1016/j.joms.2014.04.031.

9. Holzinger D, Seemann R, Matoni N, Ewers R, Millesi W, Wutzl A. Effect of dental implants on bisphosphonate-related osteonecrosis of the jaws. J Oral Maxillofac Surg. 2014;72(10):1937. doi:10.1016/j.joms.2014.04.037. e1-8.

10. Lopez-Cedrun JL, Sanroman JF, Garcia A, Penarrocha M, Feijoo JF, Limeres J, et al. Oral bisphosphonate-related osteonecrosis of the jaws in dental implant patients: a case series. Br J Oral Maxillofac Surg. 2013;51(8):874-9. doi:10.1016/j.bjoms.2013.06.011.

11. Chadha GK, Ahmadieh A, Kumar S, Sedghizadeh PP. Osseointegration of dental implants and osteonecrosis of the jaw in patients treated with bisphosphonate therapy: a systematic review. J Oral Implantol. 2013;39(4): 510-20. doi:10.1563/AAID-JOI-D-11-00234.

12. Javed F, Almas K. Osseointegration of dental implants in patients undergoing bisphosphonate treatment: a literature review. J Periodontol. 2010;81(4):479-84. doi:10.1902/jop.2009.090587. 
13. Bedogni A, Bettini G, Totola A, Saia G, Nocini PF. Oral bisphosphonateassociated osteonecrosis of the jaw after implant surgery: a case report and literature review. J Oral Maxillofac Surg. 2010;68(7):1662-6. doi:10.1016/j.joms.2010.02.037.

14. Schiegnitz E, Al-Nawas B, Kammerer PW, Grotz KA. Oral rehabilitation with dental implants in irradiated patients: a meta-analysis on implant survival. Clin Oral Investig. 2014;18(3):687-98. doi:10.1007/s00784-013-1134-9.

15. Niibe K, Ouchi T, Iwasaki R, Nakagawa T, Horie N. Osteonecrosis of the jaw in patients with dental prostheses being treated with bisphosphonates or denosumab. J Prosthodont Res. 2015;59(1):3-5. doi:10.1016/j.jpor.2014.08.001.

16. Tam Y, Kar K, Nowzari H, Cha HS, Ahn KM. Osteonecrosis of the jaw after implant surgery in patients treated with bisphosphonates-a presentation of six consecutive cases. Clin Implant Dent Relat Res. 2014;16(5):751-61. doi:10.1111/cid.12048.

17. Kwon TG, Lee CO, Park JW, Choi SY, Rijal G, Shin HI. Osteonecrosis associated with dental implants in patients undergoing bisphosphonate treatment. Clin Oral Implants Res. 2014;25(5):632-40. doi:10.1111/clr.12088.

18. Jacobsen C, Metzler P, Rossle M, Obwegeser J, Zemann W, Gratz KW. Osteopathology induced by bisphosphonates and dental implants: clinical observations. Clin Oral Investig. 2013;17(1):167-75. doi:10.1007/s00784-0120708-2.

19. Lazarovici TS, Yahalom R, Taicher S, Schwartz-Arad D, Peleg O, Yarom N. Bisphosphonate-related osteonecrosis of the jaw associated with dental implants. J Oral Maxillofac Surg. 2010;68(4):790-6. doi:10.1016/j.joms.2009.09.017.

20. Nisi M, La Ferla F, Karapetsa D, Gennai S, Miccoli M, Baggiani A, et al. Risk factors influencing BRONJ staging in patients receiving intravenous bisphosphonates: a multivariate analysis. Int J Oral Maxillofac Surg. 2015; 44(5):586-91. doi:10.1016/j.ijom.2015.01.014.

21. Kwon YD, Ohe JY, Kim DY, Chung DJ, Park YD. Retrospective study of two biochemical markers for the risk assessment of oral bisphosphonate-related osteonecrosis of the jaws: can they be utilized as risk markers? Clin Oral Implants Res. 2011;22(1):100-5. doi:10.1111/j.1600-0501.2010.01965.x.

22. Koka S, Babu NM, Norell A. Survival of dental implants in post-menopausal bisphosphonate users. J Prosthodont Res. 2010;54(3):108-11. doi:10.1016/j. jpor.2010.04.002.

23. Marx RE, Sawatari Y, Fortin M, Broumand V. Bisphosphonate-induced exposed bone (osteonecrosis/osteopetrosis) of the jaws: risk factors, recognition, prevention, and treatment. J Oral Maxillofac Surg. 2005;63(11): 1567-75. doi:10.1016/j.joms.2005.07.010.

24. Al-Sabbagh M, Robinson FG, Romanos G, Thomas MV. Osteoporosis and bisphosphonate-related osteonecrosis in a dental school implant patient population. Implant Dent. 2015;24(3):328-32. doi:10.1097/ID. 0000000000000234

25. Famili P, Quigley S, Mosher T. Survival of dental implants among postmenopausal female dental school patients taking oral bisphosphonates: a retrospective study. Compend Contin Educ Dent. 2011;32(6):E106-9.

26. Goss A, Bartold M, Sambrook P, Hawker P. The nature and frequency of bisphosphonate-associated osteonecrosis of the jaws in dental implant patients: a South Australian case series. J Oral Maxillofac Surg. 2010;68(2): 337-43. doi:10.1016/j.joms.2009.09.037.

27. Lo JC, O'Ryan FS, Gordon NP, Yang J, Hui RL, Martin D, et al. Prevalence of osteonecrosis of the jaw in patients with oral bisphosphonate exposure. J Oral Maxillofac Surg. 2010;68(2):243-53. doi:10.1016/j.joms.2009.03.050.

28. Bell BM, Bell RE. Oral bisphosphonates and dental implants: a retrospective study. J Oral Maxillofac Surg. 2008;66(5):1022-4. doi:10.1016/.joms.2007.12.040.

29. Grant BT, Amenedo C, Freeman K, Kraut RA. Outcomes of placing dental implants in patients taking oral bisphosphonates: a review of 115 cases. J Oral Maxillofac Surg. 2008;66(2):223-30. doi:10.1016/j.joms.2007.09.019.

30. Fugazzotto PA, Lightfoot WS, Jaffin R, Kumar A. Implant placement with or without simultaneous tooth extraction in patients taking oral bisphosphonates: postoperative healing, early follow-up, and the incidence of complications in two private practices. J Periodontol. 2007;78(9):1664-9. doi:10.1902/jop.2007.060514.

31. Jeffcoat MK. Safety of oral bisphosphonates: controlled studies on alveolar bone. Int J Oral Maxillofac Implants. 2006;21(3):349-53.

32. Boquete-Castro A, Gomez-Moreno G, Calvo-Guirado JL, Aquilar-Salvatierra A, Delgado-Ruiz RA. Denosumab and osteonecrosis of the jaw. A systematic analysis of events reported in clinical trials. Clin Oral Implants Res. 2015. doi:10.1111/clr.12556.

33. Bamias A, Kastritis E, Bamia C, Moulopoulos LA, Melakopoulos I, Bozas G, et al. Osteonecrosis of the jaw in cancer after treatment with bisphosphonates: incidence and risk factors. J Clin Oncol. 2005;23(34):8580-7. doi:10.1200/JCO.2005.02.8670

34. Carmagnola D, Celestino S, Abati S. Dental and periodontal history of oncologic patients on parenteral bisphosphonates with or without osteonecrosis of the jaws: a pilot study. Oral Surg Oral Med Oral Pathol Oral Radiol Endod. 2008;106(6):e10-5. doi:10.1016/j.tripleo.2008.07.011.

35. Jabbour Z, El-Hakim M, Mesbah-Ardakani P, Henderson JE, Albuquerque Jr R. The outcomes of conservative and surgical treatment of stage 2 bisphosphonate-related osteonecrosis of the jaws: a case series. Int J Oral Maxillofac Surg. 2012;41(11):1404-9. doi:10.1016/j.jom.2012.05.012.

36. Kos M, Kuebler JF, Luczak K, Engelke W. Bisphosphonate-related osteonecrosis of the jaws: a review of 34 cases and evaluation of risk. J Craniomaxillofac Surg. 2010;38(4):255-9. doi:10.1016/j.jcms.2009.06.005.

37. Kumar SK, Meru M, Sedghizadeh PP. Osteonecrosis of the jaws secondary to bisphosphonate therapy: a case series. J Contemp Dent Pract. 2008:9(1):63-9.

38. Kyrgidis A, Vahtsevanos K, Koloutsos G, Andreadis C, Boukovinas I, Teleioudis

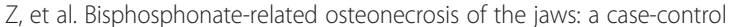
study of risk factors in breast cancer patients. J Clin Oncol. 2008;26(28): 4634-8. doi:10.1200/JCO.2008.16.2768.

39. Vahtsevanos K, Kyrgidis A, Verrou E, Katodritou E, Triaridis S, Andreadis CG et al. Longitudinal cohort study of risk factors in cancer patients of bisphosphonate-related osteonecrosis of the jaw. J Clin Oncol. 2009;27(32): 5356-62. doi:10.1200/JCO.2009.21.9584.

40. Walter C, Al-Nawas B, Grotz KA, Thomas C, Thuroff JW, Zinser V, et al. Prevalence and risk factors of bisphosphonate-associated osteonecrosis of the jaw in prostate cancer patients with advanced disease treated with zoledronate. Eur Urol. 2008;54(5):1066-72. doi:10.1016/j.eururo.2008.06.070.

41. Walter C, Grotz KA, Kunkel M, Al-Nawas B. Prevalence of bisphosphonate associated osteonecrosis of the jaw within the field of osteonecrosis. Support Care Cancer. 2007;15(2):197-202. doi:10.1007/s00520-006-0120-z.

42. Yarom N, Yahalom R, Shoshani Y, Hamed W, Regev E, Elad S. Osteonecrosis of the jaw induced by orally administered bisphosphonates: incidence, clinical features, predisposing factors and treatment outcome. Osteoporos Int. 2007;18(10):1363-70. doi:10.1007/s00198-007-0384-2.

43. Hasegawa Y, Kawabe M, Kimura H, Kurita K, Fukuta J, Urade M. Influence of dentures in the initial occurrence site on the prognosis of bisphosphonaterelated osteonecrosis of the jaws: a retrospective study. Oral Surg Oral Med Oral Pathol Oral Radiol. 2012;114(3):318-24. doi:10.1016/j.000o.2012.04.002.

44. DeBaz C, Hahn J, Lang L, Palomo L. Dental Implant Supported Restorations Improve Quality of Life in Osteoporotic Women. Int J Dent. 2015;2015: 451923. doi:10.1155/2015/451923.

45. Grötz KA, Al-Nawas B. Persisting alveolar sockets-a radiologic symptom of BPONJ? J Oral Maxillofac Surg. 2006;64(10):1571-2. doi:10.1016/j.joms.2006.05.041.

46. Hutchinson M, O'Ryan F, Chavez V, Lathon PV, Sanchez G, Hatcher DC, et al. Radiographic findings in bisphosphonate-treated patients with stage 0 disease in the absence of bone exposure. J Oral Maxillofac Surg. 2010;68(9): 2232-40. doi:10.1016/j.joms.2010.05.003.

47. Wray D, Barlow D, Crighton A, Devennie H, Foster E, Kennedy D et al. Oral Health Management of Patients Prescribed Bisphosphonates Dental Clinical Guidance. Dundee: 2011

48. Awad MA, Rashid F, Feine JS. Overdenture Effectiveness Study Team C. The effect of mandibular 2-implant overdentures on oral health-related quality of life: an international multicentre study. Clin Oral Implants Res. 2014;25(1): 46-51. doi:10.1111/clr.12205

49. Boven GC, Raghoebar GM, Vissink A, Meijer HJ. Improving masticatory performance, bite force, nutritional state and patient's satisfaction with implant overdentures: a systematic review of the literature. J Oral Rehabil. 2015;42(3):220-33. doi:10.1111/joor.12241.

50. Kyrgidis A, Triaridis S, Kontos K, Patrikidou A, Andreadis C, Constantinidis J, et al. Quality of life in breast cancer patients with bisphosphonate-related osteonecrosis of the jaws and patients with head and neck cancer: a comparative study using the EORTC QLQ-C30 and QLQ-HN35 questionnaires. Anticancer Res. 2012;32(8):3527-34.

51. Montefusco V, Gay F, Spina F, Miceli R, Maniezzo M, Teresa Ambrosini M, et al. Antibiotic prophylaxis before dental procedures may reduce the incidence of osteonecrosis of the jaw in patients with multiple myeloma treated with bisphosphonates. Leuk Lymphoma. 2008;49(11):2156-62. doi:10.1080/10428190802483778.

52. Grötz KA, Al-Nawas B. Laufzettel Risiko-Evaluation bei antiresorptiver Therapie vor Implantation (Bisphosphonat-, Denosumab-Medikation). DGINET 
53. Grötz KA, Al-Nawas B, Terheyden H. Implantate und BisphosphonatTherapie. Implantologie. 2013;21(1):53-9.

54. Grötz KA, Schmidt BL, Walter C, Al-Nawas B. Bei welchen BisphosphonatPatienten darf ich eigentlich implantieren? Ein systematisches Review. Z Zahnärztl Impl. 2010;26(2):153-61.

55. Krimmel M, Ripperger J, Hairass M, Hoefert S, Kluba S, Reinert S. Does dental and oral health influence the development and course of bisphosphonaterelated osteonecrosis of the jaws (BRONJ)? Oral Maxillofac Surg. 2014;18(2): 213-8. doi:10.1007/s10006-013-0408-3.

56. Tsao C, Darby I, Ebeling PR, Walsh K, O'Brien-Simpson N, Reynolds E, et al. Oral health risk factors for bisphosphonate-associated jaw osteonecrosis. J Oral Maxillofac Surg. 2013;71(8):1360-6. doi:10.1016/j.joms.2013.02.016.

57. Thumbigere-Math V, Michalowicz BS, Hodges JS, Tsai ML, Swenson KK, Rockwell $L$, et al. Periodontal disease as a risk factor for bisphosphonaterelated osteonecrosis of the jaw. J Periodontol. 2014;85(2):226-33. doi:10. 1902/jop.2013.130017.

58. Martin DC, O'Ryan FS, Indresano AT, Bogdanos P, Wang B, Hui RL, et al. Characteristics of implant failures in patients with a history of oral bisphosphonate therapy. J Oral Maxillofac Surg. 2010;68(3):508-14. doi:10.1016/j.joms.2009.09.055.

59. Shabestari GO, Shayesteh YS, Khojasteh A, Alikhasi M, Moslemi N, Aminian A, et al. Implant placement in patients with oral bisphosphonate therapy: a case series. Clin Implant Dent Relat Res. 2010;12(3):175-80. doi:10.1111/j. 1708-8208.2009.00150.X.

60. Zahid TM, Wang BY, Cohen RE. Influence of bisphosphonates on alveolar bone loss around osseointegrated implants. J Oral Implantol. 2011;37(3): 335-46. doi:10.1563/AAID-JOI-D-09-00114.

61. Memon S, Weltman RL, Katancik JA. Oral bisphosphonates: early endosseous dental implant success and crestal bone changes. A retrospective study. Int J Oral Maxillofac Implants. 2012;27(5):1216-22.

62. Yip JK, Borrell LN, Cho SC, Francisco H, Tarnow DP. Association between oral bisphosphonate use and dental implant failure among middle-aged women. J Clin Periodontol. 2012;39(4):408-14. doi:10.1111/j.1600-051X.2012. 01854.x.

63. Lopez-Jornet P, Camacho-Alonso F, Martinez-Canovas A, Molina-Minano F, Gomez-Garcia F, Vicente-Ortega V. Perioperative antibiotic regimen in rats treated with pamidronate plus dexamethasone and subjected to dental extraction: a study of the changes in the jaws. J Oral Maxillofac Surg. 2011; 69(10):2488-93. doi:10.1016/j.joms.2011.02.059.

\section{Submit your manuscript to a SpringerOpen ${ }^{\circ}$ journal and benefit from:}

- Convenient online submission

- Rigorous peer review

- Immediate publication on acceptance

- Open access: articles freely available online

- High visibility within the field

- Retaining the copyright to your article 